\title{
KEMIRINGAN LERENG DAN GRANULOMETRI SEDIMEN GISIK TANJUNG MERAH, BITUNG SULAWESI UTARA
}

\author{
(Beach Slope and Sediment Granulometry at Tanjung Merah, Bitung North
} Sulawesi)

\author{
Isman Sapsuha ${ }^{1 *}$, Royke M. Rampengan ${ }^{1}$, Ersy T. Opa ${ }^{1}$, Hermanto W. K. \\ Manengkey ${ }^{1}$, Wilmy E. Pelle ${ }^{1}$, Ferdinand F.Tilaar ${ }^{2}$
}

1. Program Studi IImu Kelautan, Fakultas Perikanan dan IImu Kelautan, Unsrat

2. Program Studi Manajemen Sumberdaya Perairan, Fakultas Perikanan dan IImu Kelautan, Unsrat

*e-mail: ismansapsuha71@gmail.com

Beach slope and sediment granulometry is one of the importat aspect in coastal management. Beach offers a variety of functions and potential to be utilized. In the interests of phisical use in the beach, coastal structure in the form of groynes has been built. Actually, the groin has been used as a dock. This research was conducted with the aim of revealing the slope and granulometry sediment in Tanjung Merah beach. The results obtained, the beach slope is considered sloping and very sloping, the composition of the sediment consists mainly of medium sand, fine sand and very fine sand. Sediment distribution analysis obtained results, the main grain size was mainly in the form of medium sand, sorting was mainly classified as poor, skewness was mostly asymmetrie strong to large size, most curtosis was mesokurtic. The results of the study indicate the occurrence of the process of erosion and deposition ia certain spaces on the beach studied.

Keywords: Tanjung Merah, beach slope, sediment granulometry

Kemiringan lereng dan granulometri sedimen gisik merupakan salah satu aspek penting dalam pengelolaan pantai. Gisik menawarkan beragam fungsi dan potensi untuk dimanfaatkan. Dalam kepentingan pemanfaatan lahan gisik, berbagai modifikasi dilakukan oleh manusia. Pada gisik di Tanjung Merah, telah dibangun struktur pantai berupa groin. Secara aktual, groin tersebut telah difunsikan sebagai dermaga. Penelitian ini dilakukan dengan tujuan mengungkapkan kemiringan dan granulometri sedimen di gisik Tanjung Merah. Hasil penelitian yang diperoleh, lereng gisik terkriteria miring dan sangat miring, komposisi sedimen terutama terdiri dari pasir sedang, pasir halus, dan pasir sangat halus. Analisis distribusi memperoleh hasil, rataan empirik terutama berupa pasir sedang, penyortiran terutama terklasifikasi buruk, kemencengan terbanyak berupa asimetris kuat ke ukuran besar, peruncingan terbanyak berupa mesokurtik. Hasil studi mengindikasikan terjadi proses erosi dan deposisi pada ruang-ruang tertentu di gisik yang ditelaah.

Kata kunci : Tanjung Merah, kemiringan lereng, granulometri sedimen 


\section{PENDAHULUAN}

Gisik merupakan penampilan bentuklahan yang lazim ditemui pada daerah pantai. Menurut Gross (1993), gisik merupakan bentuklahan di daerah pantai yang letaknya antara jangkauan aksi gelombang saat pasang tertinggi dan jangkauan aksi gelombang saat surut terendah, dengan material lepas sebagai ciri khasnya. Gisik berubah secara aktual setiap waktu, karena berlangsungnya proses pantai (gelombang, pasang surut) dan bahkan oleh dinamika manusia yang beraktivitas di lahan tersebut (Komar, 1976 dalam Williams dan Micallef, 2009). Lebih lanjut diungkapkan, sering perubahan yang terjadi sangat besar, baik secara alami ataupun oleh adanya pengaruh antropogenik.

Menurut Bird (2008), secara alami bentuk gisik dapat berubah oleh kerja gelombang dan arus yang memindahkan sedimen dari satu tempat ke tempat lainnya, demikian juga morfologi gisik sering berubah oleh aktivitas pasang surut dan angin. Pengaruh antropogenik dalam merubah gisik ditunjukkan oleh adanya pembangunan struktur di pantai.

Menurut Williams dan Micallef (2009) keberagaman fungsi yang ditawarkan lahan gisik merupakan faktor yang sering memicu adanya konflik kepentingan. Untuk mereduksi hal tersebut diperlukan adanya kegiatan pengelolaan terhadap lahan gisik. Pengelolaan yang baik harus didasarkan pada kajian ilmiah yang baik pula. Salah satu informasi yang menunjang kegiatan pengelolaan lahan gisik adalah menyangkut morfometri gisik dan granulometri sedimen.

Secara aktual, di kawasan pantai Tanjung Merah terdapat berbagai bentuklahan, salah satunya adalah bentuklahan gisik. Keberadaan bentuklahan gisik di kawasan pantai ini menarik untuk ditelaah karena berinteraksi dengan adanya bentukan antropogenik yaitu adanya struktur pantai berupa groin. Struktur pantai berupa groin ini juga difungsikan sebagai dermaga untuk kapal/perahu yang berlabuh di kawasan pantai tersebut. Selain itu, groin tersebut melindungi kolam dermaga dari aktivitas sedimentasi akibat pergerakan sedimen pantai.

Kehadiran bentuklahan gisik di kawasan pantai Tanjung Merah yang dipadukan dengan adanya struktur pantai merupakan corak geomorfologi yang menarik untuk ditelaah. Untuk itu, penelitian ini diarahkan menjawab permasalahan menyangkut bagaimana morfometri gisik dan granulometri sedimennya. Tujuan penelitian ini diarahkan untuk mengungkapkan morfometri lereng gisik dan komposisi serta distribusi sedimen gisik di Tanjung Merah.

\section{METODE PENELITIAN}

Kegiatan penelitian ini dilaksanakan dalam ruang lingkup kerja Laboratorium Geomorfologi Pantai diwujudkan dengan menerapkan metode deskriptif terhadap data hasil survey yang dilakukan

\section{Lokasi dan Peralatan Penelitian}

Lokasi penelitian di mana serangkaian kegiatan pengambilan sampel dan pengukuran dikerjakan, terletak di kawasan pantai Tanjung Merah yang secara administratif berada pada posisi geografis $1^{\circ} 24^{\prime} 26^{\prime \prime} U$ dan $125^{\circ} 7^{\prime} 15^{\prime \prime} \mathrm{T}$ dalam wilayah Kota Bitung, Provinsi Sulawesi Utara. Lokasi penelitian selengkapnya diperlihatkan pada Gambar 01.

Seperangkat peralatan digunakan dalam kegiatan penelitian ini. Tabel 01 menampilkan peralatanperalatan yang digunakan beserta deskripsi singkat kegunaannya. 


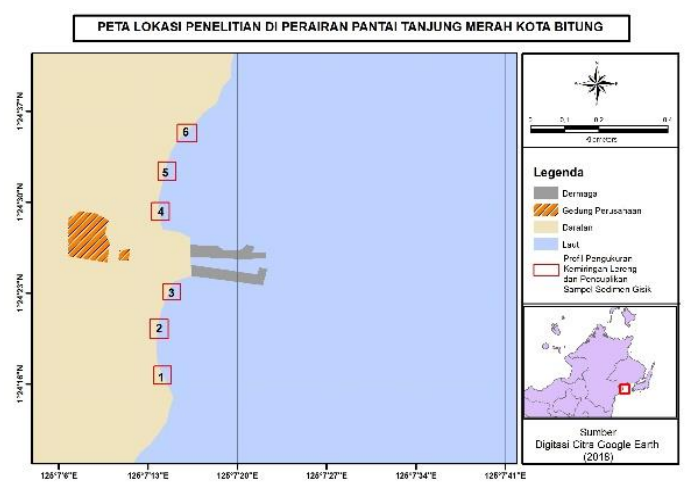

Gambar 01. Profil-Profil Pengukuran Pada Lahan Gisik di Tanjung Merah.

Tabel 01. Peralatan Penelitian

\begin{tabular}{|c|l|l|}
\hline No & Nama & \multicolumn{1}{c|}{ Kegunaan } \\
\hline 1 & $\begin{array}{l}\text { Ayakan } \\
\text { Sedimen }\end{array}$ & $\begin{array}{l}\text { Sebagai Penyaring } \\
\text { Contoh Sedimen }\end{array}$ \\
\hline 2 & $\begin{array}{l}\text { Timbangan } \\
\text { analitik }\end{array}$ & $\begin{array}{l}\text { Menimbang contoh } \\
\text { sedimen }\end{array}$ \\
\hline 3 & $\begin{array}{l}\text { Sekop } \\
\text { kecil }\end{array}$ & $\begin{array}{l}\text { Pencuplik contoh } \\
\text { sedimen }\end{array}$ \\
\hline 4 & Profiler & $\begin{array}{l}\text { Pengukur } \\
\text { kemiringan lereng }\end{array}$ \\
\hline 5 & $\begin{array}{l}\text { Perangkat } \\
\text { lunak } \\
\text { komputer }\end{array}$ & $\begin{array}{l}\text { Pengolahan kata, } \\
\text { data, grafik dan } \\
\text { peta }\end{array}$ \\
\hline
\end{tabular}

\section{Pengukuran Morfometri Lereng dan Penarikan Contoh Sedimen}

Pengumpulan data morfometri gisik dilakukan menggunakan profiler. Peralatan ini dirakit menggunakan dua tonggak sejajar yang dihubungkan dengan tali sepanjang $50 \mathrm{~cm}$ dan memiliki skala sudut. Morfometri lereng diukur dengan mendirikan kedua tonggak tegak lurus pada lahan di mana perbedaan ketinggian menyebabkan tali membentuk sudut yang dapat dilihat nilainya pada skala sudut. Pengukuran morfometri lereng dilakukan pada sebanyak enam profil di lahan gisik. Data pengukuran morfometri lereng yang diperoleh dari hasil observasi lapangan dianalisis berdasarkan kaidah trigonometri antara panjang lahan $\left(x_{i}\right)$ dengan formula $x_{i}=z$ $\cos \alpha$ dan tinggi lahan $\left(y_{i}\right)$ dengan formula $y_{i}=z \sin \alpha$; (Supit, 2000; Langie, 2001; Kairupan, 2002). Hasil perhitungan morfometri lereng diklasifikasikan menurut Sunarto (1991) dalam Langie (2001), sebagai berikut : lereng datar $(0-2 \%)$, lereng landai $(3-$ $7 \%)$, lereng miring $(8-13 \%)$, lereng sangat miring (14-20\%), lereng curam $(21-50 \%)$, lereng sangat curam (56 $140 \%$ ), dan lereng terjal (>140\%).

Penarikan contoh sedimen dilakukan di titik-titik yang ditentukan pada profil gisik demikian juga dengan jumlah dan lapisan sedimen yang dicuplik. Contoh sedimen diambil pada permukaan lahan dengan bantuan sekop kecil, dan kemudian dikemas dalam wadah plastik yang sudah dinomori untuk selanjutnya dibawa ke laboratorium guna penanganan dan pengolahan data granulometrinya. Contoh sedimen diambil pada empat profil, yaitu 1, 3, 4, dan 6 , dengan titiktiik pencuplikan yakni atas, tengah, dan bawah. Sedimen yang tercuplik, selanjutnya ditangani di laboratorium dengan melakukan pencucian dan pengeringan. Setelah sedimen kering, dilakukan pemisahan sesuai dengan ukuran ayakan $0.05 \mathrm{~mm} ; 0.08 \mathrm{~mm}$; $0,125 \mathrm{~mm} ; 0,2 \mathrm{~mm} ; 0,315 \mathrm{~mm} ; 0,5 \mathrm{~mm}$ $0,8 \mathrm{~mm} ; 1,25 \mathrm{~mm} ; 2,00 \mathrm{~mm} ; 3,15 \mathrm{~mm}$ $5.00 \mathrm{~mm} ; 8,00 \mathrm{~mm} ; 12,5 \mathrm{~mm} ; 20,00$ $\mathrm{mm}$. Sedimen yang tertingal pada masing-masing ayakan ditimbang.

Hasil pemisahan sedimen menurut ukuran butirnya, menjadi dasar determinasi komposisi sedimen gisik. Penentuan komposisi sedimen gisik dilakukan menggunakan skala AFNOR.

Tabel 02. Skala AFNOR
\begin{tabular}{|l|l|}
\hline Jenis Sedimen & Ukuran, mm (a) \\
\hline Batu & $>20(<-13)$ \\
\hline Kerikil & $20-2(-13$ s/d -3$)$ \\
\hline Pasir Kasar & $2-0,8(-3$ s/d 1$)$ \\
\hline Pasir Sedang & $0,8-0,315(1$ s/d 5$)$ \\
\hline Pasir Halus & $0,315-0,125(5$ s/d \\
\hline Pasir Sangat Halus & $9)$ \\
\hline Debu & $0,125-0,05(9$ a/d 13$)$ \\
\hline
\end{tabular}


Sumber : Pinot (1992) dalam Kondjol (2003)

Hasil pemisahan ukuran butir sedimen juga menjadi dasar penggambaran grafik peubah distribusi granulometri sedimen, untuk hitungan ukuran pemusatan dan penyebaran partikel sedimen berupa rataan empirik $(\mathrm{Mz})$, penyortiran $\left(\sigma_{1}\right)$, kemencengan $\left(\mathrm{S}_{\mathrm{k}}\right)$, peruncingan $(\mathrm{Kg})$.

Untuk menafsirkan hasil perhitungan yang diperoleh, komposisi ukuran partikel dalam distribusinya diklasifikasikan sesuai Folk dan Ward (1957) dalam Kondjol (2003), seperti berikut.

(a) Rataan Empirik $(\mathrm{Mz})=\left(\varphi_{16}+\varphi_{50}+\right.$ $\left.\varphi_{84}\right) / 3$

(b) Penyortiran $\left(\sigma_{1}\right)=\left(\varphi_{84}-\varphi_{16}\right) / 4+$ $\left(\varphi_{95}-\varphi_{5}\right) / 6,6$

(c) Kemencengan $\quad\left(S_{k}\right)=\left[\left(\varphi_{16}+\varphi_{84}-\right.\right.$ $\left.\left.2 \varphi_{50}\right) / 2\left(\varphi_{84}-\varphi_{16}\right)\right]+\left[\left(\varphi_{5}+\varphi_{95}-\right.\right.$ $\left.\left.2 \varphi_{50}\right) / 2\left(\varphi_{95}-\varphi_{5}\right)\right]$

(d) Peruncingan $(\mathrm{KG})=(\varphi 95-\varphi 5) /$ $2,44(\varphi 75-\varphi 25)$.

\section{HASIL DAN PEMBAHASAN}

Morfometri lereng gisik di Tanjung Merah ditemukan terkriteria pada lereng miring sampai sangat miring. Lereng miring terukur pada profil 1 dan 4 menunjukkan kriteria lereng yang sama dengan nilai besaran masing-masing 12,92\% (Profil 1), $12,39 \%$ (profil 4). Sedangkan pada profil 2, 3, 5, dan 6 kriteria lereng sangat miring dengan nilai besaran 18,58\% (Profil 2), 14,83\% (Profil 3), $18,08 \%$ (Profil 5), dan 14,83\% (Profil 6). Kemiringan lereng pada keseluruhan profil yang terukur di gisik pantai Tanjung Merah, ditampilkan pada Gambar 02.

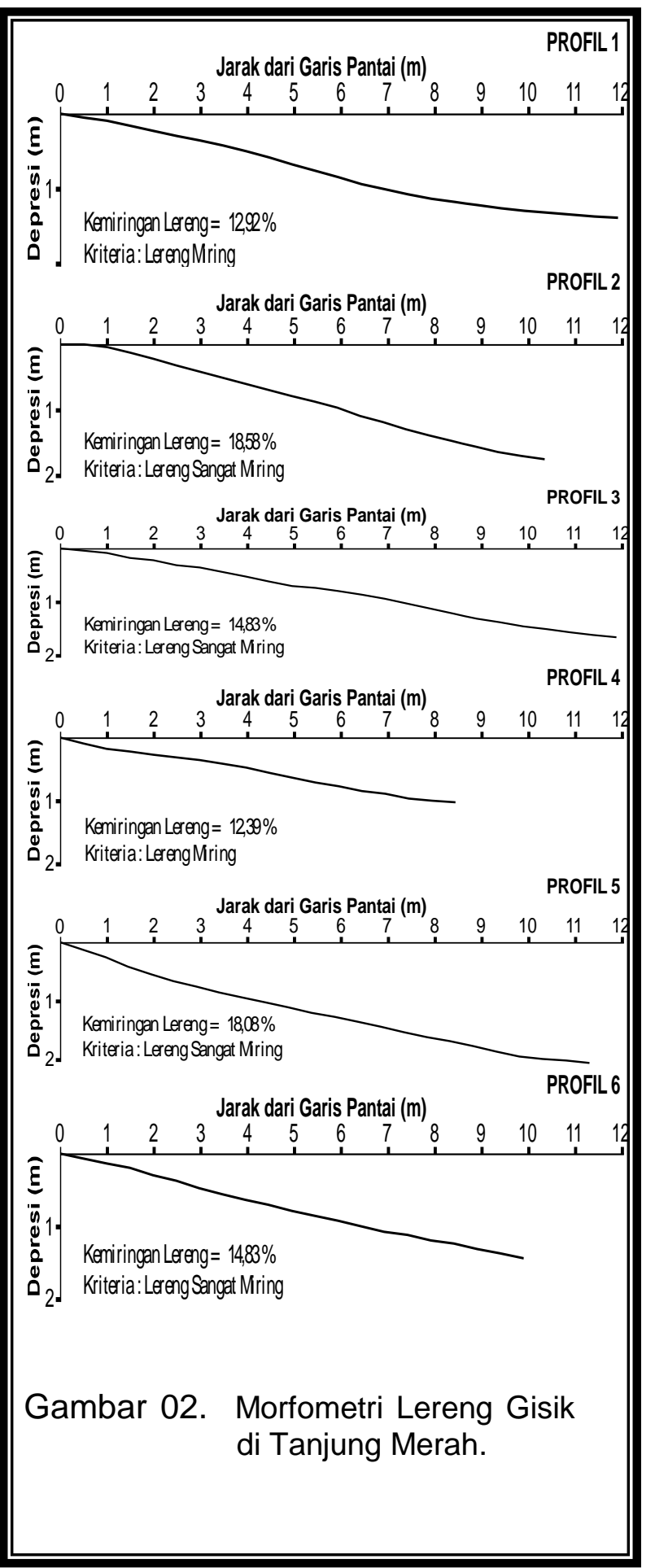




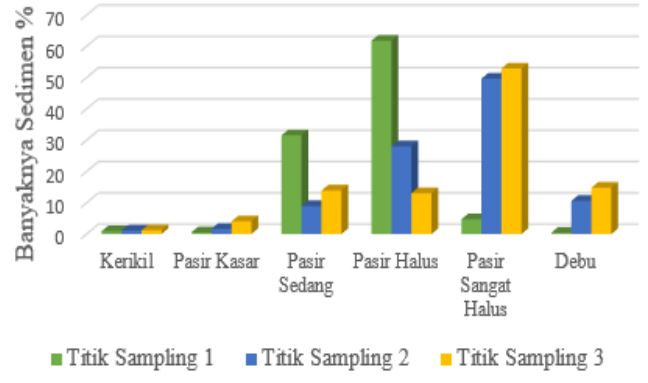

Gambar 03. Komposisi Sedimen Profil 1.

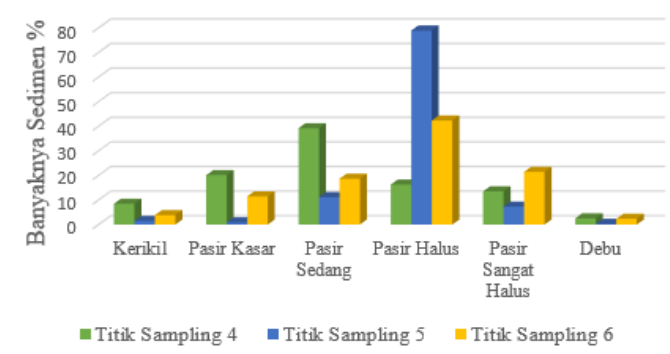

Gambar 04. Komposisi Sedimen Profil 3

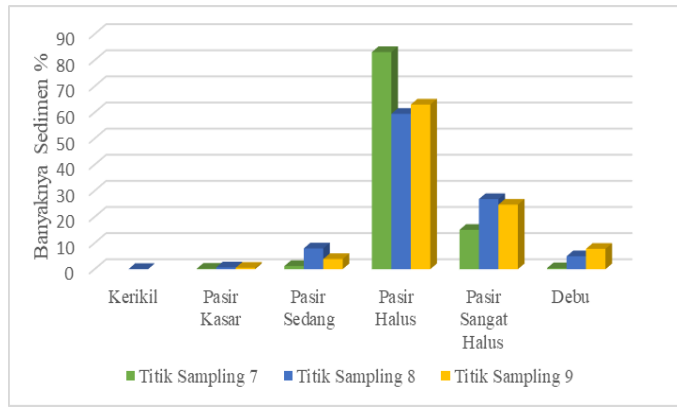

Gambar 05. Komposisi Sedimen Profil 4.

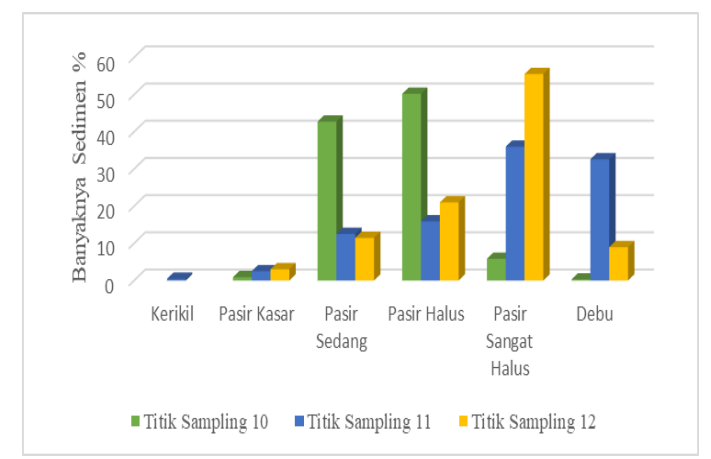

Gambar 06. Komposisi Sedimen Profil 6.

Komposisi sedimen gisik di pantai Tanjung Merah pada Profil 1, memperlihatkan adanya perbedaan terhadap struktur sedimen yang menghampari lahan gisik. Pada bagian atas profil, yaitu titik sampling 1, memiliki sedimen dengan struktur yang lebih kasar dibandingkan dengan bagian bawah profil gisik (titik sampling 2 dan 3). Pada bagian atas profil gisik sedimen terbanyak berupa pasir halus dengan kehadiran sedimen berupa pasir sedang yang cukup banyak (sekitar 40\%). Sebaliknya pada bagian tengah dan bawah profil gisik ditandai dengan komposisi sedimen terbanyak berupa pasir sangat halus dan dengan peningkatan jumlah material debu.

Struktur sedimen yang terdapat pada Profil 3 tampak komposisinya lebih kasar dibandingkan dengan yang terdapat pada Profil 1. Seperti yang ditampilkan pada Gambar 03, di bagian atas profil gisik (titik sampling 4) dihampari utamanya oleh material berupa pasir sedang, sedangkan bagian tengah dan bawah profil gisik terutama disusun oleh pasir halus. Pada ruang gisik Profil 3 ini, memperlihatkan peningkatan volume material sedimen kasar berupa pasir kasar dan kerikil (pada bagian atas dan bawah ruang gisik), dibandingkan dengan komposisi sedimen pada Profil 1.

Komposisi sedimen yang menghampari ruang gisik pada Profil 4, menampilkan persamaan pada ruang gisik bagian atas, tengah, maupun bawah. Di keseluruhan ruang gisik pada profil ini utamanya berupa pasir halus diikuti oleh sedimen berukuran pasir sangat halus.

Pada ruang gisik Profil 6, menampilkan keadaan komposisi sedimen yang mirip dengan yang terdapat pada Profil 1. Sedimen yang menghampari ruang gisik bagian atas memiliki struktur lebih kasar dibandingkan dengan yang menghampari ruang gisik bagian tengah dan bawah. Pada ruang gisik bagian atas terutama berupa sedimen berukuran pasir halus dan pasir sedang, sedangkan pada ruang gisik 
bagian tengah dan bawah terutama berupa pasir sangat halus diikuti pasir halus dan debu.

Tabel 03. Peubah Distribusi Granulome-tri Sedimen Gisik Tanjung Merah

\begin{tabular}{|c|c|c|c|c|}
\hline \multirow{2}{*}{$\begin{array}{l}\text { Peub } \\
\text { ah }\end{array}$} & \multirow{2}{*}{ Kriteria } & \multirow{2}{*}{$\begin{array}{c}\text { Titik } \\
\text { Sampling }\end{array}$} & \multicolumn{2}{|c|}{ Jumlah } \\
\hline & & & $\mathrm{N}$ & $\%$ \\
\hline \multirow{3}{*}{$\begin{array}{l}\text { Rata } \\
\text { an } \\
\text { Empi } \\
\text { rik }\end{array}$} & Pasir Kasar & 4 & 1 & 8,33 \\
\hline & Pasir Sedang & $\begin{array}{l}1,5,6,7 \\
8,9,10\end{array}$ & 7 & 58,33 \\
\hline & Pasir Halus & $\begin{array}{l}2,3,11, \\
12\end{array}$ & 4 & 33,34 \\
\hline \multirow{4}{*}{$\begin{array}{c}\text { Peny } \\
\text { ortira } \\
n\end{array}$} & $\begin{array}{l}\text { Tersortir Sangat } \\
\text { Baik }\end{array}$ & 7 & 1 & 8,33 \\
\hline & Baik & 5,10 & 2 & 16,67 \\
\hline & Sedang & $1,8,9$ & 3 & 25,00 \\
\hline & Buruk & $\begin{array}{l}2,3,4,6, \\
11,12\end{array}$ & 6 & 50,00 \\
\hline \multirow{4}{*}{$\begin{array}{l}\text { Kem } \\
\text { ence } \\
\text { ngan }\end{array}$} & $\begin{array}{l}\text { Asimetris Kuat } \\
\text { ke-Ukuran Besar }\end{array}$ & $\begin{array}{lr}2, & 3, \\
10, & 11, \\
12 & \end{array}$ & 6 & 50,00 \\
\hline & $\begin{array}{l}\text { Simetris } \\
\text { Granulometri }\end{array}$ & 7,8 & 2 & 16,67 \\
\hline & $\begin{array}{l}\text { Asimetris ke- } \\
\text { Ukuran Kecil }\end{array}$ & 1 & 1 & 8,33 \\
\hline & $\begin{array}{l}\text { Asimetris Kuat } \\
\text { ke-Ukuran Kecil }\end{array}$ & $4,5,9$ & 3 & 25,00 \\
\hline \multirow{5}{*}{$\begin{array}{l}\text { Peru } \\
\text { ncing } \\
\text { an }\end{array}$} & Platikurtik & 2,11 & 2 & 16,67 \\
\hline & Mesokurtik & $\begin{array}{l}3,4,6 \\
10\end{array}$ & 4 & 33,34 \\
\hline & Leptokurtik & 1,5 & 2 & 16,67 \\
\hline & $\begin{array}{l}\text { Sangat } \\
\text { Leptokurtik }\end{array}$ & $8,9,12$ & 3 & 25,00 \\
\hline & Leptokurtik Sekali & 7 & 1 & 8,33 \\
\hline
\end{tabular}

Berdasarkan Tabel 03 kriteria rataan empirik granulometri sedimen, maka dapat dikatakan bahwa sedimen yang menghampari gisik Tanjung Merah ini adalah sedimen yang berukuran halus. Hal tersebut bertolak dari hasil analisis granulometri yang menunjukkan lebih dari $90 \%$ rataan empirik granulometri sedimen gisik kawasan pantai ini terklasifikasi sebagai Pasir Halus dan Pasir Sedang. Nilai penyortiran yang dikombinasikan dengan nilai peruncingan kurva granulometri, menunjukkan bahwa di beberapa tempat kawasan gisik ini memiliki sebaran sedimen dengan ukuran yang cukup beragam. Khususnya pada ruang-ruang gisik yang diwakili oleh titik-titik sampling dengan kriteria penyortiran buruk dan kriteria peruncingan platikurtik dan mesokurtik. Pada ruang-ruang tersebut, ukuran granulometri sedimennya menyebar cukup jauh dari rataan empiriknya. Pada titik sampling sedimen 7, yaitu ruang gisik bagian atas pada Profil 4, struktur sedimennya berada pada ukuran yang sangat seragam (tersortir sangat baik dengan kriteria peruncingan Leptokurtik Sekali).

$$
\text { Kemencengan }
$$

kurva granulometri sedimen menunjukkan di beberapa kawasan ruang gisik pantai Tanjung Merah ini cenderung mengalami proses erosi, beberapa dalam keadaan seimbang antara erosi dan deposisi, dan juga beberapa kawasan mengalami proses deposisi. Pada ruang-ruang gisik yang memiliki kemencengan terkriteria asimetris kuat ke ukuran besar, cenderung proses yang sedang berlangsung adalah proses erosi. Sebaliknya ruang-ruang yang kurva sedimennya terkriteria asimetris kuat ke ukuran kecil, proses yang sedang berlangsung adalah proses deposisi. Ruang-ruang yang terkriteria simetris granulometri, menunjukkan bahwa proses erosi dan deposisi secara seimbang bekerja pada ruang tersebut.

Berdasarkan hasil kajian dalam penelitian ini, gisik di pantai Tanjung Merah dapat dikatakan memiliki material tergolong berukuran halus. Gisik yang dihampari oleh sedimen berukuran halus, semestinya berpadanan dengan lereng yang berkriteria datar sampai landai. Faktanya, gisik di kawasan pantai Tanjung Merah, berkriteria lereng miring sampai sangat miring.

Keberadaan komposisi sedimen dan nilai-nilai peubah distribusi granulometri sedimen yang dipadukan dengan kriteria kemiringan lereng, menunjukkan pada ruang gisik di pantai Tanjung Merah ini, proses erosi terjadi cukup intensif. Kondisi faktor hidrooseanografi faktual yang bekerja pada ruang pantai di tempat ini, tampaknya cukup efektif memicu terjadinya proses erosi. 
Khususnya pada ruang gisik di sebelah Utara dari groin, proses erosi terindikasi sangat intensif terjadi. Hal tersebut tampak dari peubah kemencengan distribusi granulometri untuk titik-titik pengambilan sampel sedimen 10, 11, dan 12 (Profil 6) yang semuanya terkriteria asimetris kuat ke ukuran besar. Faktor hidrooseanografi yang bekerja pada ruang gisik ini sangat aktif mengangkut material sedimen halus keluar dari bagian pantai ini, meninggalkan sedimen yang berukuran lebih kasar di tempat itu.

Ruang gisik pada Profil 1, bagian tengah dan bawah, proses erosi juga berlangsung. Demikian juga pada ruang gisik Profil 3 di bagian bawah. Sedimen berukuran halus, aktif diangkut keluar dari bagian ruangruang gisik tersebut, meninggalkan sedimen berukuran lebih kasar.

Pada beberapa tempat di ruang gisik, deposisi sedimen terjadi. Di ruang gisik bagian atas dan tengah pada Profil 3, proses deposisi terjadi akibat transpor sedimen dihalangi oleh adanya groin. Walaupun demikian, di ruang bawah pada Profil 3, struktur groin tidak dapat lagi menghalangi terangkutnya sedimen keluar dari ruang tersebut. Proses deposisi, juga terjadi pada Profil 4, baik di bagian atas, tengah, maupun bawah dari profil ini. Deposisi sedimen pada profil ini, terjadi akibat penimbunan sedimen yang dilakukan oleh aktivitas manusia. Hasil pengerukan sedimen dalam kolam pelabuhan, ditimbun pada ruang gisik pada Profil 4 ini. Itulah sebabnya, peubah kemencengan dari distribusi granulometri sedimen pada profil ini (titik 7, 8, dan 9), diperoleh simetris granulometri dan asimetris kuat ke ukuran kecil.

\section{KESIMPULAN}

Hasil pengolahan data pada lahan gisik di pantai Tanjung Merah Kota Bitung sesuai dengan hasil yang diperoleh telah dapat diidentifikasi proses pembentukannya berdasarkan tujuan yang ditetapkan, beberapa kesimpulan dapat dikemukan sebagai berikut.

1. Kemiringan Lereng Gisik pantai Tanjung Merah terkriteria pada lereng miring sampai lereng sangat miring. Komposisi sedimen yang menghampari lahan gisik utamanya berupa pasir sedang, pasir halus, dan pasir sangat halus. Hasil analisis distribusi granulometri sedimen adalah rataan empirik terbanyak terklasifikasi pada pasir sedang, penyortiran terbanyak tersortir buruk, kemencengan terbanyak asimetris kuat ke ukuran besar, dan peruncingan terbanyak terklasifikasi pada mesokurtik.

2. Komposisi sedimen, peubah distribusi granulometri sedimen, dan kriteria kemiringan lereng gisik pantai Tanjung Merah, mengindikasikan proses erosi sedang berlangsung. Deposisi yang terjadi di beberapa tempat pada ruang gisik, merupakan akumulasi sedimen akibat groin menghalangi transpor sedimen sepanjang pantai dan timbunan hasil pengerukan oleh aktivitas manusia.

\section{DAFTAR PUSTAKA}

Bird, E., 2008. Coastal Geomorphology : An Introduction. Second Edition. John Wiley \& Sons, Ltd. England. 411 hal.
Kondjol, S., $2003 . \quad$ Distribusi Granulometri Sedimen Dasar Perairan Labuan Manggadaging, Belang. Skripsi. FPIK, Universitas Sam Ratulangi, Manado

$\begin{array}{rr}\text { Kairupan, A.A.F., } 2002 . & \text { Proses } \\ \text { Pembentukan Lahan Gisik di } \\ \text { Pantai Kelurahan Batulubang } \\ \text { Kecamatan Bitung Selatan. }\end{array}$ 
Skripsi. FPIK, Universitas Sam Ratulangi, Manado. 71 hal.

Langie, P.E., 2001. Identifikasi Proses Pembentukan Lahan Gisik di Selat Lembeh Bagian Barat. Skripsi. FPIK, Universitas Sam Ratulangi, Manado. 69 hal.

Supit, A.A.G., 2000. Morfologi Gisik di Kawasan Wisata Tasik Ria -
Mokupa. Skripsi. FPIK, Universitas Sam Ratulangi, Manado. 76 hal.

Williams A. dan A. Micallef, 2009. Beach Management, Principles and Practice. Earthscan. United Kingdom. 446 hal 